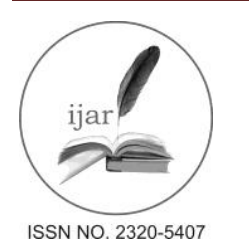

Journal homepage: http://www.journalijar.com
Journal DOI: 10.21474/IJAR01

INTERNATIONAL JOURNAL

OF ADVANCED RESEARCH

RESEARCH ARTICLE

\title{
THE CAUSAL RELATIONSHIP BETWEEN THE COMPONENTS OF SOCIAL ENTREPRENEUR AND ECONOMIC AND SOCIAL SECURITY
}

\author{
Assoc.Prof. Ornpapha Chutikorntaweesin Ph. D., Jureeporn Makingrilas Ph. D., Vichai Lamsutthi Ph. D., \\ Nicharat Sangthong Ph. D., Rattasart Phongphaew Ph. D. \\ California University (CUFCE), USA.
}

\section{Manuscript Info}

Manuscript History:

Received: 19 March 2016

Final Accepted: 26 April 2016

Published Online: May 2016

Key words:

causal relationship,

social entrepreneur,

Leadership for social change,

Morality/Virtue

*Corresponding Author

Ornpapha
Chutikorntaweesin.

\begin{abstract}
The purposes of this research were 1) to study the relationship between the components of social entrepreneurs and economic and social security, and 2) to present the causal relationship model between the components of social entrepreneur and economic and social security. The researcher applied the quantitative research method in conducting this research, using the questionnaires to collect the primary data from 380 samples. The statistics used in this study are Pearson Correlation, and Structural Equation Model (SEM). The research results show that the components of social entrepreneurs in the aspect of vision of entrepreneurs, social innovation, morality/virtue, and leadership for social change, all these components have the relationship with economic and social security. The analysis of the causal relationship between the components of social entrepreneur influencing economic and social security is relevant to the empirical data, by that all components of social entrepreneur have an influence on economic and social security.
\end{abstract}

Copy Right, IJAR, 2016,. All rights reserved.

\section{Introduction:-}

In the midst of the globalization, many businesses have to adapt themselves to develop, to grow, and to survive by generating the most wealth and profit, which is the original financial performance evaluation of business. However, the financial evaluation might be appropriate to the old business which invested in the long-term production, and it is not an important thing to indicate the overall success. When the time of technology comes, it is very necessary for businesses to create value in the future through the investment about stakeholders (Kaplan and Norton, 1992).

The economic security of business is the stability of finance of business in order to manage the resources of the organization for the benefit and good life quality of personnel and stakeholders. The economic security comes from operating business to generate earning and profit, which brings about the business growth to be able to have selfreliance without the request for the assistance from other organizations (Meeboonlue, 2010). The economic security is connected to the social security which means the stability about occupation, working, income, welfare both during working and after retirement, which covers the healthcare, and other privilege (Office of the National Economics and Social Development Board, 2011). In addition, the social security also comes from the powerful support to every sector so that they can select their own life style and the way of participation in economy and politics with value and honor. It is also the way to increase the potentiality and capability of community to resolve the local problem, to support the occupation aggregation that is relevant to the local potentiality, and to support the private sector and people sector to be the leader to develop the community privilege (Office of the National Economics and Social Development Board, 2005).

From these reasons, the concept of social entrepreneur is developed to be the active working direction, which is not only to resolve problem, but also to find the approach to eliminate the limit or obstacles of the social entrepreneur in 
the aspects of a lack of money and resources, a lack of the support of the related organization, and a lack of capability to find the solution for the more complicated social problem by using the business skills as a tool to achieve the social objectives. Therefore, the social entrepreneur should have vision and innovation (Bacq and Janssen, 2008; Catford, 1998), should have the outstanding diversity between the social entrepreneur and the profit organization, and should rely on the path of morality so that it becomes the habit (Sullivan Mort et al., 2002). Moreover, the role of leadership for social change is who can persuade other to create and use their own thought, and to prioritize the leadership for social change in the positive way for stakeholders and the whole society (Catford, 1998; Sullivan Mort et al., 2002). In Thailand, it can be seen that there is the wakefulness, potentiality, and possibility of the social enterprise (Thai Social Enterprise Office, 2012). Therefore, the social entrepreneur is a new choice for entrepreneur, but it lacks the expertise in business, plus with the business risk, also the appropriate model in the context of Thailand (Mali, 2014). This research recognizes the importance of this problem, thus studied the causal relationship between the components of social entrepreneur and economic and social security in order to retrieve the components influencing economic and social security. The researcher aims to publicize the research results to social entrepreneurs and others who are interested so that they can operate business along with doing social activities in order to create the prosperity to business to be self-reliant, and to create the benefit to stakeholders in the society.

\section{Purposes of research:-}

1. To study the relationship between the components of social entrepreneurs and economic and social security.

2. To present the causal relationship model between the components of social entrepreneur and economic and social security.

\section{Literature review:-}

In this research, the researcher studied the concept, theory, and related research. The first concept is about the social entrepreneur who takes the role to change the society; it is relevant to the definition in the report of Global Entrepreneurship Monitor: GEM that the social entrepreneurship means the entrepreneur who recognizes the social problem and tries to find the new solution to resolve the problem and to create the social value by trying to use the opportunity to launch the new business or by doing the social activities with the expectation to satisfy the need of society or community more than to generate the business profit to the shareholders. Therefore, the social entrepreneur focuses on these skills: 1) to expand the capability and to maintain the connection and business allies, 2 ) to develop the capacity to manage the demand of overall stakeholders, 3) to develop the capacity to joint venture with other non-profit organizations, and 4) to keep the natural resources and to set the strategic plan to generate the growth and sustainability to the organization (Drayton, 2006; Wei-Skillern et al., 2007).

In addition, the researcher also studied the concept about economic and social security, which mainly considers the abundance of resources, trading, industry, finance, and life quality of people. The indicators of economic and social security of people are that people can earn for their living and family, and the personal income per capita. In addition, the feeling safe of people in both life and property is that when the problem occurs, people are considered with justice; this is the social security. Moreover, the problem of unemployment is also important and causes and effect on the security (Office of the National Economics and Social Development Board, 2005).

\section{Material and Methods:-}

The researcher applied the quantitative research in conducting this study. The secondary data were retrieved by reviewing concept and theory from the document, academic articles, and related research from both domestic and international sources. The primary data were collected by using the questionnaire verified with the Index of ItemObjective Congruence (IOC) which the IOC is $0.8-1$; this means this questionnaire is relevant to the purposes of research. Then, it was passed through the try-out process with a sample group of 30 persons to finding the reliability level with the method of Alpha Coefficient of Cronbach (1970), whose reliability coefficient is 0.872. This demonstrated that this questionnaire was reliable and could be really used in collecting data. The populations of this study are the SMEs entrepreneurs in the Eastern region of Thailand; the sample size is indicated by using the table of Yamane (1970) at the reliability level of 95\%, retrieving 380 samples, then used the sample random sampling. The statistics used in this study are Pearson Correlation, and Structural Equation Model (SEM). The research period is since September to December 2015 (4 months). 


\section{Results:-}

Analysis about the demographic profiles:-

With regard to the demographic profiles of all 380 SMEs entrepreneurs, the results show that $50.80 \%$ are female, and 49.20 are male. $34.20 \%$ aged between $41-50$ years. $48.40 \%$ graduated the Bachelor degree. $32.90 \%$ are the entrepreneurs in the sector of wholesale/retail/automobile repair. $44.70 \%$ have operated business for more than 20 years respectively.

\section{Research results}

Correlation analysis between the components of social entrepreneur and economic and social security:-

With regard to the correlation between the components of social entrepreneur and economic and social security, the results show that the correlation between the components of social entrepreneur and economic and social security have the relationship with the statistical significance at the level of 0.01 ; by that the correlation is between $0.612-0.791$ (see table 1).

Vision of entrepreneur (SE1) has the relationship with economic and social security with the statistical significance at the level of 0.01 , by that the correlation is 0.777 .

Social innovation (SE2) has the relationship with economic and social security with the statistical significance at the level of 0.01 , by that the correlation is 0.612 .

Morality/Virtue (SE3) has the relationship with economic and social security with the statistical significance at the level of 0.01 , by that the correlation is 0.786 .

Leadership for social change (SE4) has the relationship with economic and social security with the statistical significance at the level of 0.01 , by that the correlation is 0.791 .

Table 1 Correlation between the components of social entrepreneur and economic and social security

\begin{tabular}{|c|c|c|c|c|c|}
\hline Variables & SE1 & SE2 & SE3 & SE4 & SES \\
\hline SE1 & 1 & $0.688^{* * *}$ & $0.699^{* * *}$ & $0.599^{* * *}$ & $0.777^{* * *}$ \\
\hline SE2 & & 1 & $0.782^{* * *}$ & $0.224^{* * *}$ & $0.612^{* * *}$ \\
\hline SE3 & & & 1 & $0.386^{* *}$ & $0.786^{* *}$ \\
\hline SE4 & & & & 1 & $0.791^{* *}$ \\
\hline SES & & & & & 1 \\
\hline
\end{tabular}

** with the statistical significance at the level of 0.01

The analysis of the causal relationship model of social entrepreneur influencing economic and social security:-

With regard to the causal relationship model of social entrepreneur influencing economic and social security, the results show that the variables in the aspects of vision of entrepreneur (SE1), social innovation (SE2), morality/Virtue (SE3), and leadership for social change (SE4) are the real components of the causal relationship model of social entrepreneur influencing economic and social security. The researcher adjusted the components so that the relevant index is in an acceptable standard, in which $\chi^{2}=0.98 ; \mathrm{df}=1 ; \mathrm{P}$-value $=0.32219$; RMSEA $=$ 0.000 , which demonstrates that the causal relationship between the model of social entrepreneur influencing the creation of economic and social security is relevant to the empirical data.

The analysis of the causal relationship model of social entrepreneur influencing economic and social security show that the component weight of the variables in the aspects of vision of entrepreneur, social innovation, morality/virtue, leadership for social change, and economic and social security has the statistical significance $(\mathrm{P}<0.01)$. This means the variables in the aspects of vision of entrepreneur, social innovation, morality/virtue, and leadership for social change are the important variables indicating economic and social security, by that the weight of the variables is between 0.09-0.62.

When considering the influence value, it is found that the components of social entrepreneur influencing economic and social security are consisted of social innovation, morality/virtue, and leadership for social change have a direct 
influence on economic and social security; while social innovation, vision of entrepreneur, and leadership for social change have an indirect influence on economic and social security via morality/virtue.

In addition, vision of entrepreneur, social innovation, and leadership for social change have an influence on morality/virtue with the statistical significance at the level of 0.01 (see figure 1).

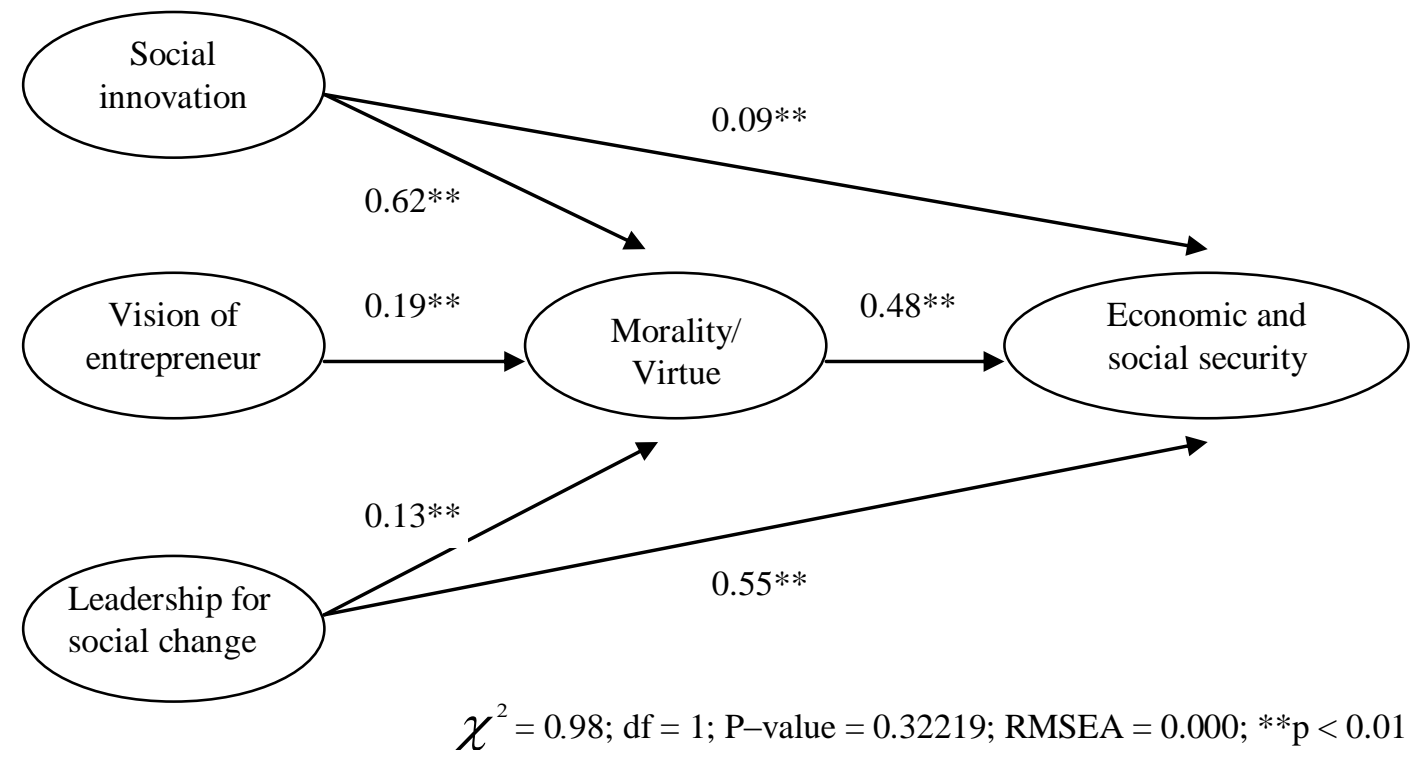

Figure 1 The causal relationship model of social entrepreneur influencing economic and social security (created by the researcher)

\section{Discussion:-}

The components of social entrepreneur influencing economic and social security are consisted of first, social innovation; which is the capacity of social entrepreneur in sharing knowledge, setting the operation base that does not cause effects on society, community, and environment, in being creative leader, and in participating in motivating others to operate the good business. This is relevant to the concept of Catford (1998) that the success of social entrepreneur depends on the innovation of the entrepreneur; primarily the social entrepreneur should have the explicit vision or paradigm that the social entrepreneurship is not the charity or making merit, but the method to reduce or to connect the gap in society with the transparent approach; this is also relevant to the study of Zahra, Gedajlovic, Neubaum, and Shulman (2009) who presented that social entrepreneurship combines the social activities and process which leads to find the definition and to take advantage from the opportunity to create the social wealth; this is relevant to the principles of the social entrepreneurship of Nontanatorn (2010) that to reach the success in the social entrepreneurship firstly requires innovation, the social entrepreneur should think beyond for finding the newly creative solution by relying on the organization goal without any concern about the limited resources. The second component of social entrepreneur is morality/virtue; the social entrepreneur should operate fair trading reflecting the cost and cost of living, and should have conscious mind to avoid operating business that causes an impact on organization and society, plus with the transparent business operation and showing respect and fairness to customers. This is relevant to the concept of Sullivan Mort et al. (2002) that the dimension of morality will help the social entrepreneur to be successful in doing the social mission and in creating the differences between the social entrepreneur and the profit organization. The positive morality is consisted of love, loyalty, sincerity, and empathy. The demonstration of morality is the mindful action, not the coincidence; and the social entrepreneur will rely on the path of morality so that it becomes the habit. The third component of social entrepreneur is leadership for social change; it is the concept that creates the opportunity to people to have self-reliance, and creates the cooperation to develop the society and environment in the innovative dimension for distributing income and creating jobs to the disadvantages; this is also the method to reduce the inequality in the society at the root of the problem for the sustainability. This is relevant to the study of Davis (2002) that as change makers, these relentless innovators infect society with a sense of hope and optimism that a better world is possible. This is how the vicious cycle of pessimism; despair and malignant development can become a virtuous circle of decent work, fair, just and environmentally healthy communities. Sullivan Mort et al. (2002) also said that the social entrepreneur tries to upgrade the life quality of the disadvantages, to let others to recognize the social concern and realize the importance of the leadership for social change in the better way. 
The social mission must be explicit and impartial, which will cause an effect on the social entrepreneur to acknowledge and evaluate the opportunity in operating business to creating the social value to customers and stakeholders. The social entrepreneur cannot operate the mission solely but requires the cooperation with the surrounding contexts of the enterprise to change the society. This is also relevant to the study of Baber, Jain, and Baber (2012) referring to understand the role of social entrepreneurship for the upliftment of society. Generating employment and diminishing poverty are the biggest challenges for any developing country so entrepreneurship indicates an opportunities for social development and improves the quality growth of life. The main aim of the social entrepreneurship is to further collective and environmental goals. Social entrepreneur is generally correlated with non-profit sector, but this not secludes them from not earning profit. This is also relevant to the concept of Catford (1998) that the social entrepreneur can persuade others to create their own concept and allow others to use it; this will help developing the business more than relying on the old structure or working system. The standard indicator of this success is the effective change; which is relevant to the study of Seelos and Mair (2004) about social entrepreneurship the contribution of individual entrepreneurs to sustainable development. They found that a unique role of SE as "The contribution of individual entrepreneurs to Sustainable Development." The goal of development nowadays is that the social entrepreneur has the initiative thought of business operation aiming to the benefit of society; social entrepreneurs are much better than companies at scanning for opportunities and building up grassroots efforts from very limited capital. By using corporate funding instead of purely philanthropic sources for capital, the objective of social entrepreneurship is to reach the sustainable development.

\section{References:-}

1. Baber, R., Jain, S., and Baber, P. (2012). Social Entrepreneurs: Changing Face of Society. Retrieve from https://www.researchgate.net/publication/236003969.

2. Bacq, S., and Janssen, F. (2008). From social entrepreneurship as a practice to a legitimate field of research: Literature review and classification. European Summer University Conference on Entrepreneurship. Bod $\varnothing$, Noeway.

3. Catford, J. (1998). Social Entrepreneurs Are Vital for Health Promotion - But They Need Supportive Environments Too. Health Promotion International, 13(2): 95-97.

4. Cronbach, L. J. (1970). Essentials of psychological testing ( $3^{\text {rd }}$ ed.). New York: Harper \& Row.

5. Davis, S. (2002). Social Entrepreneurship: Towards an Entrepreneurial Culture for Social and Economic Development. The Youth Employment Summit, September 7-11, 2002.

6. Drayton, B. (2006). Everyone a change-maker: Social entrepreneurship's ultimate goal. Innovation. MIT Press with Harvard University and George Mason University.

7. Kaplan, R. S. and Norton, D.P. (1992). The Balanced Scorecard: Measures that Drive Performance. Harvard Business Review, (January-February): 71-79.

8. Mali, K. (2014). Social enterprise in Thailand. Journal of Economics and Managing Strategy, 1(2): 104-112.

9. Meeboonlue, J. (2010). National Security: Creation of Sustainable Thai Nation. Academic document. Strategic Studies Center.

10. Nontanatorn, P. (2010). The Management of Corporate Social Responsibility. Nonthaburi: Think Beyond Books.

11. Office of the National Economics and Social Development Board. (2005). Creation of Stable and Sustainable Economic Base. Retrieve from http://www.nesdb.go.th/portals//0news/annual_meet//48docu/.2pdf.

12. Office of the National Economics and Social Development Board. (2011). Summary of the Eleventh National Economic and Social Development Plan (2012-2016). Retrieve from http://www.2oae.go.th/EVA/download/Plan/SummaryPlan11_thai.pdf.

13. Seelos, C., and Mair, J. (2004). Social Entrepreneurship: the Contribution of Individual Entrepreneurs to Sustainable Development. IESE Business School - Universidad de Navarra.

14. Sullivan Mort, G., Weerawardena, J. and Carnegie, K. (2002). Social Entrepreneurship: Towards Conceptualization. International Journal of Nonprofit and Voluntary Sector Marketing, 8(1): 76-88.

15. Thai Social Enterprise Office. (2012). General knowledge about social enterprise. Retriee from http://oranuch.nsdv.go.th/main/attachments/237_2012text1.pdf.pdf.

16. Wei-Skillern,J.C., Austin, J.E., Leonard, H. B. and Stevenson, H.H. (2007). Entrepreneurship in the Social Sector. Thousand Oaks, CA, Sage Publication.

17. Yamane, T. (1970). Statistic : An Introductory Analysis. Tokyo: Harper International Edition.

18. Zahra, S. A., Gedajlovic, E., Neubaum, D. O., and Shulman, J. M. (2009). A typology of social entrepreneurs: Motives, search processes and ethical challenges. Journal of Business Venturing, 24: 519-532. 